\title{
Pengaruh Pendayagunaan Zakat Produktif terhadap Pemberdayaan Mustahiq pada LAZ Yayasan Solo Peduli Surakarta
}

\author{
Oleh: Mila Sartika*
}

\begin{abstract}
The following article originates from the result of the field research. The research has been conducted in LAZ (Lembaga Amail Zakat) Yayasan Solo Peduli Surakarta. LAZ Yayasan Solo Peduli Surakarta constitutes one of the biggest LAZ at Surakarta. The main problem of this research is the influence of productive zakat fund toward mustahiq. The research design is quantitative and its analysis is statistic by using a simple regression. The result of this research revealed that the productive zakat fund for year 2007 influence on mustahiq income significantly. The significant level or its grade reaches 0,045 or sig $<0.05$. In other words there is a positive correlation between productive zakat fund toward mustahiq income
\end{abstract}

Keywords: pendayagunaan, zakat produktif, pemberdayaan, dan mustahiq.

\section{Pendahuluan}

Kemiskinan merupakan bahaya besar bagi umat manusia dan tidak sedikit umat yang jatuh peradabannya hanya karena kefakiran. Karena itu seperti sabda Nabi yang menyatakan bahwa kefakiran itu mendekati pada kekufuran. ${ }^{1}$ Islam sebagai Ad-diin telah menawarkan beberapa doktrin bagi manusia yang berlaku secara universal dengan dua ciri dimensi, yaitu kebahagiaan dan kesejahteraan hidup di dunia serta kebahagiaan dan kesejahteraan hidup di akhirat.

Salah satu cara menanggulangi kemiskinan adalah dukungan orang yang mampu untuk mengeluarkan harta kekayaan mereka berupa dana zakat kepada mereka yang kekurangan. Zakat merupakan salah satu dari lima nilai instrumental yang strategis dan sangat berpengaruh pada tingkah laku ekonomi manusia dan

* Penulis adalah alumni Program Studi Ekonomi Islam Fakultas Ilmu Agama Islam Univesitas Islam Indonesia Yogyakarta. Email: d4n3_07@yahoo.com

${ }^{1}$ Dikutip dalam Abdurrachman Qadir (2001). Zakat (Dalam Dimensi Mabdah dan Sosial), ed. 1, cet. 2. (Jakarta: RajaGrafindo Persada), hlm. 24. 
masyarakat serta pembangunan ekonomi umumnya. ${ }^{2}$ Tujuan zakat tidak sekedar menyantuni orang miskin secara konsumtif, tetapi mempunyai tujuan yang lebih permanen yaitu mengentaskan kemiskinan. ${ }^{3}$

Salah satu yang menunjang kesejahteraan hidup di dunia dan menunjang hidup di akherat adalah adanya kesejahteraan sosial-ekonomi. Ini merupakan seperangkat alternatif untuk mensejahterakan umat Islam dari kemiskinan dan kemelaratan. Untuk itu perlu dibentuk lembaga-lembaga sosial Islam sebagai upaya untuk menanggulangi masalah sosial tersebut.

Sehubungan dengan hal itu, maka zakat dapat berfungsi sebagai salah satu sumber dana sosial-ekonomi bagi umat Islam. Artinya pendayagunaan zakat yang dikelola oleh Badan Amil Zakat tidak hanya terbatas pada kegiatan- kegiatan tertentu saja yang berdasarkan pada orientasi konvensional, tetapi dapat pula dimanfaatkan untuk kegiatan-kegiatan ekonomi umat, seperti dalam program pengentasan kemiskinan dan pengangguran dengan memberikan zakat produktif kepada mereka yang memerlukan sebagai modal usaha.

Zakat memiliki peranan yang sangat strategis dalam upaya pengentasan kemiskinan atau pembangunan ekonomi. Berbeda dengan sumber keuangan untuk pembangunan yang lain, zakat tidak memiliki dampak balik apapun kecuali ridha dan mengharap pahala dari Allah semata. Namun demikian, bukan berarti mekanisme zakat tidak ada sistem kontrolnya. Nilai strategis zakat dapat dilihat melalui: Pertama, zakat merupakan panggilan agama. Ia merupakan cerminan dari keimanan seseorang. Kedua, sumber keuangan zakat tidak akan pernah berhenti. Artinya orang yang membayar zakat, tidak akan pernah habis dan yang telah membayar setiap tahun atau periode waktu yang lain akan terus membayar. ketiga, zakat secara empirik dapat menghapus kesenjangan sosial dan sebaliknya dapat menciptakan redistribusi aset dan pemerataan pembangunan. ${ }^{4}$

Yang mendorong masyarakat Islam melaksanakan pemungutan zakat di Indonesia ini antara lain adalah: (1) keinginan umat Islam Indonesia untuk meyempurnakan pelaksanaan ajaran agamanya. Setelah mendirikan shalat, berpuasa selama bulan Ramadhan dan bahkan menunaikan ibadah haji ke Mekkah, umat Islam semakin menyadari perlunya penunaian zakat sebagai kewajiban agama; kewajiban yang harus dilaksanakan oleh setiap orang yang mampu melaksanakannya karena telah memenuhi syarat-syarat yang ditentukan.

(2) Kesadaran yang semakin meningkat di kalangan umat Islam tentang potensi zakat jika dimanfaatkan sebaik-baiknya, akan dapat memecahkan berbagai masalah sosial di Indonesia. (3) Usaha-usaha untuk mewujudkan pengembangan dan

${ }^{2}$ Ahmad M. Saefuddin (1987). Ekonomi dan Masyarakat dalam Perspektif Islam, ed.1 cet.1. (Jakarta: CV Rajawali), hlm. 71.

${ }^{3}$ Abdurrachman Qadir. Zakat., hlm. 83-84.

${ }^{4}$ Muhammad Ridwan (2005). Manajemen Baitul Maal Wa Tamwil(BMT), cet 2. (Yogyakarta: UII Press), hlm. 189-190. 
pengelolaan zakat di Indonesia makin lama makin tumbuh dan berkembang. ${ }^{5}$

Zakat yang diberikan kepada mustahiq akan berperan sebagai pendukung peningkatan ekonomi mereka apabila dikonsumsikan pada kegiatan produktif. Pendayagunaan zakat produktif sesungguhnya mempunyai konsep perencanaan dan pelaksanaan yang cermat seperti mengkaji penyebab kemiskinan, ketidakadaan modal kerja, dan kekurangan lapangan kerja, dengan adanya masalah tersebut maka perlu adanya perencanaan yang dapat mengembangkan zakat bersifat produktif tersebut.

Pengembangan zakat bersifat produktif dengan cara dijadikannya dana zakat sebagai modal usaha, untuk pemberdayaan ekonomi penerimanya, dan supaya fakir miskin dapat menjalankan atau membiayai kehidupannya secara konsisten. Dengan dana zakat tersebut fakir miskin akan mendapatkan penghasilan tetap, meningkatkan usaha, mengembangkan usaha serta mereka dapat menyisihkan penghasilannya untuk menabung

Dana zakat untuk kegiatan produktif akan lebih optimal bila dilaksanakan Lembaga Amil Zakat karena LAZ sebagai organisasi yang terpercaya untuk pengalokasian, pendayagunaan, dan pendistribusian dana zakat, mereka tidak memberikan zakat begitu saja melainkan mereka mendampingi, memberikan pengarahan serta pelatihan agar dana zakat tersebut benar-benar dijadikan modal kerja sehingga penerima zakat tersebut memperoleh pendapatan yang layak dan mandiri.

Lembaga Amil Zakat Yayasan Solo Peduli menyalurkan dana zakat produktif pada suatu program yang kemudian dikembangkan yaitu Program Pemberdayaan Ekonomi, program ini adalah program pemberdayaan pembinaan umat atau mustahiq produktif dengan memberikan bantuan modal usaha yang disalurkan dengan fasilitas Qordhul Hasan untuk bantuan modal yang berupa uang dan Muḍarabah dengan sistem gaduh untuk bantuan modal yang berupa hewan ternak. Dengan bantuan modal usaha yang diberikan Yayasan Solo Peduli, mustahiq dapat mengembangkan usaha mereka dan bisa meningkatkan pendapatan mereka

Dengan berkembangnya usaha kecil menengah dengan modal berasal dari zakat akan menyerap tenaga kerja. Hal ini berarti angka pengangguran bisa dikurangi, berkurangnya angka pengangguran akan berdampak pada meningkatnya daya beli masyarakat terhadap suatu produk barang ataupun jasa, meningkatnya daya beli masyarakat akan diikuti oleh pertumbuhan produksi, pertumbuhan sektor produksi inilah yang akan menjadi salah satu indikator adanya pertumbuhan ekonomi.

Dari penelitian ini, diharapkan dapat memberikan manfaat serta kontribusi baik bagi praktisi maupun akademisi. Bagi akademisi diharapkan hasil penelitian

${ }^{5}$ Mohammad Daud Ali (1988). Sistem Ekonomi Islam Zakat dan Wakaf, cet. 1. (Jakarta: UI Press), hlm. 52-53. 
ini mampu memberikan sumbangan pemikiran bagi ilmu syari'ah pada umumnya dan keuangan Islam pada khususnya, serta menjadi rujukan penelitian berikutnya tentang pendayagunaan zakat untuk pemberdayaan mustahiq. Adapun bagi praktisi diharapkan hasil penelitian ini dapat dijadikan acuan bagi Lembaga Amil Zakat Yayasan Solo Peduli atau pihak yang terkait di dalamnya dalam mengoptimalkan pendistribusian zakat untuk pemberdayaan mustahiq.

\section{Telaah Pustaka}

Sepengetahuan penulis pembahasan tentang pengaruh pemberian zakat terhadap pemberdayaan ekonomi umat telah banyak dibahas sebagai karya ilmiah. Dan untuk mendukung persoalan yang lebih mendalam terhadap masalah diatas, penyusun berusaha melakukan penelitian terhadapa literatur yang relevan terhadap masalah yang menjadi obyek penelitian.

Penelitian yang pernah penyusun jumpai yang berkaitan dengan zakat produktif sebagai sarana pemberdayaan ekonomi yang membahas pendapat Syekh Muhammad Arsyad Al Banjari mengenai pendayagunaan zakat untuk pemberdayaan ekonomi umat dapat dilakukan dengan memberikan sarana atau peralatan kepada mustahiq yang disesuaikan dengan kepandaian atau keterampilan yang dimiliki mustahiq. Sedangkan kepada mustahiq yang mampu mengembangkan usaha produktifnya agar diberikan modal. ${ }^{6}$

Studi lain yang berkenaan dengan zakat untuk pemberdayaan ekonomi yaitu, penelitian yang menjelaskan bahwa pendayagunaan zakat yang efektif untuk menurunkan tingkat kemiskinan tidak hanya digunakan sebagai pemenuhan konsumtif semata tetapi juga dapat dipergunakan untuk usaha-usaha pemenuhan kebutuhan produktif, bantuan pendidikan dan usaha-usaha untuk menciptakan lapangan kerja serta mengurangi pengangguran. ${ }^{7}$

Ulin Ulfa dalam penelitiannya membahas tentang pendayagunaan zakat secara produktif dalam perspektif hukum Islam adalah dapat dibenarkan, sepanjang memperhatikan kebutuhan pokok bagi masing-masing mustahiq dalam bentuk konsumtif yang bersifat mendesak untuk segera diatasi. Selain itu pendayagunaan dan pengelolaan zakat untuk usaha produktif dibolehkan oleh hukum Islam selama harta zakat tersebut cukup banyak. ${ }^{8}$

${ }^{6}$ Hosnu El Wafa (2003). "Konsepsi Zakat Produktif dalam Pemikiran Syekh Muhammad Arsyad Al Banjari (studi terhadap kitab Sabil Al Muhtadin”, Skripsi S1, Yogyakarta: UIN Sunan Kalijaga, 2003, hlm. 7.

${ }^{7}$ Alfiya Nur Hasanah (2005). "Hubungan Zakat terhadap Tingkat Kemiskinan pada BAZ Propinsi DIY Tabun 1939-2003”, Skripsi S1, Yogyakarta: UIN Sunan Kalijaga, 2005, hlm. 73 .

${ }^{8}$ Ulin Ulfa (2005). "Pendayagunaan Zakat untuk Usaha Produktif (Kajian Terhadap Pasal 16Ayat 2 UU no. 38 Tahun 1999 Tentang Pengelolaan Zakat)", Skripsi S1, Yogyakarta: UIN Sunan Kalijaga,2005, hlm. 70. 
Hazamih dalam sebuah penelitiannya membahas tentang bagaimana BAZIS DKI Jakarta dalam melakukan pendayagunaan zakat sebagai salah satu sarana dalam mengatasi kemiskinan masyarakat perorangan/individu yang ada di wilayah DKI Jakarta. ${ }^{9}$

A. Qodri Azizy dalam bukunya menyimpulkan bahwa zakat hendaknya tidak sekedar konsumtif, maka idealnya zakat dijadikan sumber dana umat. Penggunaan zakat untuk konsumtif hanyalah untuk hal-hal yang bersifat darurat. Artinya, ketika ada mustahiq yang tidak mungkin untuk dibimbing untuk mempunyai usaha mandiri atau memang untuk kepentingan mendesak, maka penggunaan konsumtif dapat dilakukan ${ }^{10}$.

Dari berbagai penelitian di atas, penyusun belum menemukan penelitian yang secara khusus membahas tentang hubungan jumlah dana (zakat produktif) yang dikeluarkan oleh Lembaga Amil Zakat untuk kegiatan produktif dengan pendapatan yang diperoleh mustahiq, sehingga Ekonomi mustahiq dapat diberdayakan, pada umumnya penelitian yang ada hanya membahas tentang pengaruh zakat terhadap pemberdayaan umat.

\section{Landasan Teori}

\section{A. Pengertian Zakat}

Ditinjau dari segi bahasa, menurut lisan orang arab, kata zakat merupakan kata dasar(masdar) dari zakat yang berarti suci, berkah, tumbuh, dan terpuji, yang semua arti ini digunakan didalam menerjemahkan Al-Qur'an dan hadits. ${ }^{11}$

Menurut terminologi syariat(istilah), zakat adalah nama bagi sejumlah harta tertentu yang telah mencapai syarat tertentu yang diwajibkan oleh Allah untuk dikeluarkan dan diberikan kepada yang berhak menerimanya dengan persyaratan tertentu pula. ${ }^{12}$.

Kaitan antara makna bahasa dan istilah ini berkaitan erat sekali, yaitu bahwa setiap harta yang sudah dikeluarkan zakatnya akan menjadi suci, bersih, baik, berkah, tumbuh dan berkembang. Dalam penggunaannya, selain untuk kekayaan, tumbuh dan suci disifatkan untuk jiwa orang yang menunaikan zakat. Maksudnya, zakat itu akan mensucikan orang yang mengeluarkannya dan

${ }^{9}$ Hazamih (1998). "Pengelolaan Zakatpada BAZ DKI Jakarta", Skripsi S1, Yogyakarta: UII Fakultas Ilmu Agama Islam, 1998, hlm. 9.

${ }^{10}$ A. Qodri Azizy (2004). Membangun Fondasi Ekonomi Umat Meneropong Prospek Berkembangnya Ekonomi Islam), cet. 1. (Yogyakarta: Pustaka Pelajar), hlm 148-149.

${ }^{11}$ Muhammad dan Ridwan Mas'ud (2005). Zakat dan Kemiskinan Instrumen Pemberdayaan Ekonomi Umat. (Yogyakarta: UII Press), hlm. 33-34.

${ }^{12}$ Dikutip oleh K. H. Didin Hafidhhuddin (2002) dalam buku, Zakat Dalam Perekonomian Modern. (Jakarta: Gema Insani), hlm. 7. 
menumbuhkan pahalanya. ${ }^{13}$ Sedangkan dalam istilah ekonomi, zakat merupakan tindakan pemindahan kekayaan dari golongan kaya kepada golongan tidak punya. ${ }^{14}$.

Zakat produktif yaitu zakat yang diberikan kepada Mustahiq sebagai modal untuk menjalankan suatu kegiatan ekonomi yaitu untuk menumbuhkembnagkan tingkat ekonomi dan potensi produktifitas Mustahiq. ${ }^{15}$

\section{B. Tujuan Zakat}

Tujuan Zakat, antara lain ${ }^{16}$ :

- Mengangkat derajat fakir-miskin dan membantunya keluar dari kesulitan hidup serta penderitaan.

- Membantu pemecahan permasalahan yang dihadapi oleh para gharimin, ibnussabil, dan mustahiq lainnya.

- Membentangkan dan membina tali persaudaraan sesama umat Islam dan manusia pada umumnya.

- Menghilangkan sifat kikir pemilik harta

- Membersihkan sifat dengki dan iri(kecemburuan sosial) dari hati orang orang miskin.

- Menjembatani jurang pemisah antara yang kaya dengan yang miskin dalam suatu masyarakat.

- Mengembangkan rasa tanggung jawab sosial pada diri seseorang, terutama pada mereka yang mempunyai harta.

- Mendidik manusia untuk berdisplin menunaikan kewajiban dan menyerahkan hak orang lain yang ada padanya.

\section{Golongan yang Berhak Menerima Zakat (Mustahiq)}

Orang - orang atau golongan yang berhak menerima zakat telah diatur dalam ajran syariat Islam, yakni ada delapan golongan (asnaf). Ketentuan ini diatur dalam Al Qur'an surat At-Taubah: 60.

${ }^{13}$ Muhammad dan Ridwan Mas'ud. Zakeat., hlm. 34

${ }^{14}$ Ibid, hlm. 42.

15 Abduracchman Qadir (2001). Zakat Dalam Dimensi Mabdah dan Sosial. Cet. 2 (Jakarta: PT. Raja Grafindo Persada), hlm. 165.

${ }^{16}$ Proyek Pembinaan Zakat dan Wakaf (1982), Pedoman Zakat (4), Jakarta: Departemen Agama), hlm. 27 - 28. 


\section{Organisasi Pengelola Zakat}

\section{Pengertian Organisasi Pengelola Zakat}

Organisasi Pengelola Zakat merupakan sebuah institusi yang bergerak di bidang pengelolaan dana zakat, infaq, dan shadaqah. ${ }^{17}$ Definisi menurut UU Nomor 38 Tahun 1999 tentang Pengelolaan Zakat adalah kegiatan perencanaan, pengorganisasian, pelaksanaan, dan pengawasan terhadap pengumpulan, pendistribusian, dan pendayagunaan zakat.

\section{Fungsi Organisasi Pengelola Zakat}

Organisasi pengelola zakat apapun bentuk dan posisinya secara umum mempunyai dua fungsi yakni ${ }^{18}$ :

\section{Sebagai perantara keuangan}

Amil berperan menghubungkan antara pihak Muzakki dengan Mustahiq. Sebagai perantara keuangan Amil dituntut menerapkan azas trust(kepercayaan). Sebagaimana layaknya lembaga keuangan yang lain, azaz kepercayaan menjadi syarat mutlak yang harus dibangun. Setiap amil dituntut mampu menunjukkan keunggulannya masing-masing sampai terlihat jelas positioning organisasi, sehingga masyarakat dapat memilihnya. Tanpa adanya positioning, maka kedudukan akan sulit untuk berkembang.

\section{Pemberdayaan}

Fungsi ini, sesungguhnya upaya mewujudkan misi pembentukan Amil, yakni bagaimana masyarakat Muzakki menjadi lebih berkah rezekinya dan ketentraman kehidupannya menjadi terjamin disatu sisi dan masyarakat Mustahiq tidak selamanya tergantung dengan pemberian bahkan dalam jangka panjang diharapkan dapat berubah menjadi Muzakki baru.

\section{E. Zakat dalam Perspektif Sosial Ekonomi ${ }^{19}$}

Dalam istilah ekonomi, zakat merupakan tindakan pemindahan kekayaan dari golongan kaya kepada golongan tidak punya. Transfer kekayaan berarti transfer sumber-sumber ekonomi. Tindakan ini tentu saja akan mengakibatkan perubahan tertentu yang bersifat ekonomis;umpamanya saja, seseorang yang

\footnotetext{
${ }^{17}$ Rifqi Muhammad (2006). "Akuntansi Lembaga Keuangan Publik Islam”, Modul Mata Kuliah. (Yogyakarta: FIAI UII), hlm 2.

${ }^{18}$ Muhammad Ridwan (2005). Manajemen Baitul Maal Wa Tamwil(BMT), cet 2. (Yogyakarta: UII Press), hlm. 207 - 208.

19 Muhammad dan Ridwan Mas'ud (2005). Zakat dan Kemiskinan Instrumen Pemberdayaan Ekonomi Umat. (Yogyakarta: UII Press), hlm. 42 - 43.
} 
menerima zakat bisa mempergunakannya untuk berkonsumsi atau berproduksi. Dengan demikian, zakat walaupun pada dasarnya merupakan ibadah kepada Allah, bisa mempunyai arti ekonomi.

Sehubungan dengan argumen di atas, Rahardjo menyatakan bahwa dengan mempergunakan pendekatan ekonomi, zakat bisa berkembang menjadi menjadi konsep muamalah(kemasyarakatan), yaitu konsep tentang cara bagaimana manusia harus melaksanakan kehidupan bermasyarakat, termasuk di dalamnya dalam bentuk ekonomi. Karena itu, ada dua konsep yang selalu dikemukakan dalam pembahasan mengenai doktrin sosial- ekonomi Islam yang saling berkaitan, yaitu pelarangan riba dan perintah membayar zakat.

\section{F. Zakat untuk Usaha Produktif ${ }^{20}$}

Pendayagunaan zakat harus berdampak positif bagi mustahiq, baik secara ekonomi maupun sosial. Dari sisi ekonomi, mustahiq dituntut benar-benar dapat mandiri dan hidup secara layak sedangkan dari sisi sosial, mustahiq dituntut dapat hidup sejajar dengan masyarakat yang lain. Hal ini berarti, zakat tidak hanya didistribusikan untuk hal-hal yang konsumtif saja dan hanya bersifat charity tetpi lebih untuk kepentingan yang produktif dan bersifat edukatif.

Kelemahan utama orang miskin serta usaha kecil yang dikerjakannya sesungguhnya tidak semata-mata pada kurangnya permodalan, tetapi lebih pada sikap mental dan kesiapan manajemen usaha. untuk itu, zakat usaha produktif pada tahap awal harus mampu mendidik mustahiq sehingga benar-benar siap untuk berubah. Karena tidak mungkin kemiskinan itu dapat berubah kecuali dimulai dari perubahan mental si miskin itu sendir. Inilah yang disebut peran pemberdayaan. Zakat yang dapat dihimpun dalam jangka panjang harus dapat memberdayakan mustahiq sampai pada dataran pengembangan usaha. programprogram yang bersifat konsumtif ini hanya berfungsi sebagai stimulan atau rangsangan dan berjangka pendek., sedangkan program pemebrdayaan ini harus diutamakan. Makna pemberdayaan dalam arti yang luas ialah memandirikan mitra, sehingga mitra dalam hal ini mustahiq tidak selamanya tergantung kepada amil.

\section{G. Pengaruh Zakat terhadap Perekonomian ${ }^{21}$}

Zakat dapat dijadikan sebagai salah satu bentuk modal bagi usaha kecil. Dengan demikian, zakat memiliki pengaruh yang sangat besar dalam berbagai

${ }^{20}$ Muhammad Ridwan (2005). Manajemen Baitul Maal Wa Tamwil(BMT), cet 2. (Yogyakarta: UII Press), hlm. 216 - 217.

${ }^{21}$ Muhammad dan Ridwan Mas'ud (2005). Zakat dan Kemiskinan Instrumen Pemberdayaan Ekonomi Umat. (Yogyakarta: UII Press), hlm. 127. 
hal kehidupan umat, di antaranya adalah pengaruh dalam bidang ekonomi. Pengaruh zakat yang lainnya adalah terjadinya pembagian pendapatan secara adil kepada masyarakat Islam.

Dengan kata lain, pengelolaan zakat secara profesional dan produktif dapat ikut membantu perekonomian masyarakat lemah dan membantu pemerintah dalam meningkatkan perekonomian negara, yaitu terberdayanya ekonomi umat sesuai dengan misi-misi yang diembannya. Diantara misi-misi tersebut adalah:

- Misi pembangunan ekonomi dan bisnis yang berpedoman pada ukuran ekonomi dan bisnis yang lazim dan bersifat universal.

- Misi pelaksanaan etika bisnis dan hukum;

- Misi membangun kekuatan ekonomi untuk Islam, sehingga menjadi sumber dana pendukung dakwah Islam

\section{Metode Penelitian}

\section{A. Jenis Penelitian}

Penelitian yang dilakukan ini adalah penelitian lapangan (field research), dengan menggunakan pendekatan kuantitatif. Dalam penelitian ini pembahasan akan menitik beratkan pada bagaimana pengaruh jumlah dana zakat yang disalurkan untuk kegiatan produktif di LAZ Yayasan Solo Peduli terhadap jumlah pendapatan yang diperoleh Mustahiq pada periode 2007. Di mana penelitian ini merupakan penelitian laporan yaitu penelitian terhadap data primer melalui wawancara dan sekunder yang didapatkan melalui berbagai sumber tidak langsung..

\section{B. Subyek Penelitian}

Subyek penelitian pada dasarnya adalah yang akan dikenai kesimpulan penelitian. Pada Penelitian yang berjudul "Pengaruh Pendayagunaan Zakat Produktif terhadap Pemberdayaan Mustahiq" yang menjadi subyeknya adalah seluruh mustahiq LAZ Yayasan Solo Peduli yang diberi zakat produktif. Namun karena beberapa kendala maka peneliti hanya menggunakan 40 orang Mustahiq yang diberi bantuan berupa ternak.

\section{Metode Pengumpulan Data}

Pada penelitian kali ini peneliti menggunakan metode pengumpulan data dengan cara: 


\section{Metode Dokumentasi}

Dilakukan dengan cara mengumpulkan data berdasarkan data-data atau laporan yang berkaitan dengan masalah penelitian.

\section{Metode Wawancara}

Peneliti mengadakan wawancara dengan tokoh lembaga atau para fungsionaris khususnya pihak manajemen pendayagunaan zakat produktif yang dianggap berkompeten dan representatif dengan masalah yang dibahas untuk memperoleh informasi mengenai pendayagunaan zakat produktif.

\section{Metode Analisis Data}

Penelitian ini mencari pengaruh jumlah dana yang disalurkan oleh LAZ terhadap pendapatan yang diperoleh mustahiq maka analisis yang digunakan adalah Regresi Sederhana dengan formulasi sebagai berikut: ${ }^{22}$

$\mathrm{Y}=\mathrm{a}+\mathrm{bx}$

Di mana: $\mathrm{Y}=$ Pendapatan Mustahiq

$\mathrm{X}=$ Jumlah bantuan dana(zakat) untuk kegiatan produktif

$\mathrm{a}=$ konstanta

$\mathrm{b}=$ koefisien regresi

b didapat dari rumus sebagai berikut:

$\mathrm{b}=\frac{\left(\sum X i Y_{i}\right)}{\left(\sum X^{2}\right)}$

\section{Data Hasil Penelitian}

\section{Tabel 4.2}

Jumlah dana (zakat) yang disalurkan untuk kegiatan produktif, pendapatan Mustahiq setelah diberi dana (zakat).

Kampung Sentra Ternak Periode 2007

\begin{tabular}{|c|c|c|}
\hline Mustahiq & Pendapatan Mustahiq & Dana (zakat) yang disalurkan \\
\hline 1 & 330000 & 865000 \\
\hline 2 & 475000 & 640000 \\
\hline 3 & 625000 & 725000 \\
\hline 4 & 630000 & 775000 \\
\hline 5 & 500000 & 1265000 \\
\hline 6 & 650000 & 1350000 \\
\hline 7 & 1000000 & 2460000 \\
\hline 8 & 450000 & 1250000 \\
\hline 9 & 455000 & 2010000 \\
\hline
\end{tabular}

${ }^{22}$ Moehar Daniel (2003). Metode Penelitian Sosial Ekonomi, cet. 2. (Jakarta: Bumi Aksara), hlm. 155. 
Mila Sartika: Pengaruh Pendayagunaan Zakat ...

\begin{tabular}{|c|c|c|}
\hline Mustahiq & Pendapatan Mustahiq & Dana (zakat) yang disalurkan \\
\hline 10 & 650000 & 675000 \\
\hline 11 & 450000 & 340000 \\
\hline 12 & 550000 & 740000 \\
\hline 13 & 550000 & 785000 \\
\hline 14 & 650000 & 2355000 \\
\hline 15 & 650000 & 710000 \\
\hline 16 & 550000 & 995000 \\
\hline 17 & 550000 & 335000 \\
\hline 18 & 300000 & 700000 \\
\hline 19 & 350000 & 995000 \\
\hline 20 & 400000 & 675000 \\
\hline 21 & 800000 & 690000 \\
\hline 22 & 650000 & 610000 \\
\hline 23 & 250000 & 695000 \\
\hline 24 & 750000 & 1060000 \\
\hline 25 & 175000 & 705000 \\
\hline 26 & 680000 & 745000 \\
\hline 27 & 850000 & 1400000 \\
\hline 28 & 850000 & 4815000 \\
\hline 29 & 450000 & 2365000 \\
\hline 30 & 650000 & 3820000 \\
\hline 31 & 500000 & 2090000 \\
\hline 32 & 1450000 & 1685000 \\
\hline 33 & 250000 & 2605000 \\
\hline 34 & 165000 & 300000 \\
\hline 35 & 400000 & 2100000 \\
\hline 36 & 725000 & 1990000 \\
\hline 37 & 825000 & 2170000 \\
\hline 38 & 500000 & 2140000 \\
\hline 39 & 280000 & 755000 \\
\hline 40 & 350000 & 780000 \\
\hline Total & 22315000 & 54165000 \\
\hline
\end{tabular}

\section{Sumber: Data Sekunder}

\section{Analisis Regresi Sederhana}

Setelah mengetahui jumlah dana (zakat) yang disalurkan untuk kegiatan produktif dan pendapatan mustahiq maka data-data tersebut dianalisis dengan menggunakan analisis regresi. Analisis regresi digunakan untuk mengetahui sejauh mana pengaruh variabel jumlah dana (zakat) yang disalurkan oleh LAZ Yayasan Solo Peduli terhadap pendapatan mustahiq di LAZ Yayasan Solo Peduli

Analisis regresi sederhana dilakukan dengan bantuan program Windows SPSS 11.5. Hasil analisis tersebut seperti terlihat pada tabel - tabel sebagai berikut: 
Tabel 4.3

Model Summary

\begin{tabular}{|c|c|c|c|c|c|c|c|c|c|}
\hline \multirow{2}{*}{ Model } & \multirow{2}{*}{$\mathbf{R}$} & \multirow{2}{*}{$\begin{array}{c}\mathbf{R} \\
\text { Square }\end{array}$} & Adjusted & \multirow{2}{*}{$\begin{array}{c}\text { Std. Error of } \\
\text { R Square }\end{array}$} & \multicolumn{5}{|c|}{ Change Statistics } \\
\cline { 5 - 10 } & & & & $\begin{array}{c}\text { R Square } \\
\text { Change }\end{array}$ & $\begin{array}{c}\text { F } \\
\text { Change }\end{array}$ & df1 & df2 & $\begin{array}{c}\text { Sig. F } \\
\text { Change }\end{array}$ \\
\hline 1 & $319^{\mathrm{a}}$ & .102 & .078 & 234061.844 & .102 & 4.302 & 1 & 38 & .045 \\
\hline
\end{tabular}

${ }^{a}$ Predictors: (Constant), dana yang disalurkan

Tabel diatas menunjukkan besaran nilai r (korelasi) sebesar 0, 319, sehingga kedua variabel tersebut dapat dikatakan memiliki korelasi atau hubungan yang erat, walaupun korelasi tersebut termasuk dalam kategori yang lemah. Selanjutnya diproleh $\mathrm{R}^{2}$ (koefisien determinan) sebesar 0, 102 atau sama dengan 10,2\%. Ini berarti kemampuan variabel dependent mampu diterangkan sebesar 10, $2 \%$ oleh variabel independent. Dan sisanya sebesar $89.8 \%$ dipengaruhi oleh faktor lain.

Tabel 4.4

ANOVA

\begin{tabular}{|ll|c|c|c|c|c|}
\hline \multicolumn{1}{|c|}{ Model } & Sum of Square & df & Mean Square & F & Sig \\
\hline 1 & Regression & $2.36 \mathrm{E}+11$ & 1 & $2.357 \mathrm{E}+11$ & 4.302 & $.045^{\mathrm{a}}$ \\
Residual & $2.08 \mathrm{E}+12$ & 38 & $5.478 \mathrm{E}+10$ & & \\
Total & $2.32 \mathrm{E}+12$ & 39 & & & \\
\hline
\end{tabular}

\section{a. Predictors: (Constant), dana yang disalurkan}

\section{b. Dependent Variabel: pendapatan}

Pada tabel 4.4 ini didapat nilai F hitung 0, 4302 dengan probabilitas 0, 045. Karena probabilitas lebih kecil dari 0, 05 maka model regresi dapat digunakan untuk memprediksi pendapatan mustahiq. Atau dapat dikatakan bahwa dana (zakat) yang disalurkan berpengaruh terhadap pendapatan.

Tabel 4.5

Coefficients

\begin{tabular}{|c|c|c|c|c|c|c|c|c|c|c|c|c|}
\hline \multirow[b]{2}{*}{ Model } & \multicolumn{2}{|c|}{$\begin{array}{l}\text { Unstandardized } \\
\text { Coefficients }\end{array}$} & \multirow{2}{*}{$\begin{array}{c}\begin{array}{c}\text { Stan- } \\
\text { dardized } \\
\text { Coeffi- } \\
\text { cients }\end{array} \\
\text { Beta }\end{array}$} & \multirow[b]{2}{*}{$\mathbf{t}$} & \multirow[b]{2}{*}{ Sig. } & \multicolumn{2}{|c|}{$\begin{array}{l}\text { 95\% Confidence Interval } \\
\text { for B }\end{array}$} & \multicolumn{3}{|c|}{ Correlation } & \multicolumn{2}{|c|}{$\begin{array}{l}\text { Colline-arity } \\
\text { Statis-tics }\end{array}$} \\
\hline & B & Std. Error & & & & $\begin{array}{l}\text { Lower } \\
\text { Bound }\end{array}$ & $\begin{array}{l}\text { Upper } \\
\text { Bound }\end{array}$ & $\begin{array}{l}\text { Zero- } \\
\text { order }\end{array}$ & Partial & Part & Tolerance & VIF \\
\hline $\begin{array}{ll}1 & \text { (constant) } \\
& \text { dana yg } \\
& \text { disalurkan }\end{array}$ & $\begin{array}{r}449208.2 \\
.080\end{array}$ & $\begin{array}{r}64146.058 \\
.039\end{array}$ & 0.319 & $\begin{array}{l}7.003 \\
2.074\end{array}$ & $\begin{array}{l}.000 \\
.045\end{array}$ & $\begin{array}{r}319351.328 \\
.002\end{array}$ & $\begin{array}{r}579065.138 \\
.159\end{array}$ & .319 & .319 & .319 & 1.000 & 1.000 \\
\hline
\end{tabular}

Dari hasil tabel di atas maka selanjutnya dilakukan uji parsial terhadap masingmasing variabel yaitu:

1. Koefisien konstanta (b)

Karena sig 0,000 atau dengan kata lain $<5 \%$ maka keputusannya adalah 
menerima $\mathrm{H}_{\mathrm{A}}$ dan menolak $\mathrm{H}_{0}$. Yang berarti koefisien konstanta (b) signifikan dalam model atau dapat diartikan bahwa koefisien konstanta mempunyai pengaruh terhadap estimasi pendapatan.

2. Koefisien variabel $X$ (dana yang disalurkan)

Karena sig 0,045 atau dengan kata lain < 5\% maka keputusannya adalah $\mathrm{H}_{0}$ ditolak dan $\mathrm{H}_{\mathrm{A}}$ diterima. Yang berarati koefisien variabel X (dana yang disalurkan) signifikan dalam model atau dapat diartikan bahwa variabel $\mathrm{X}$ (dana yang disalurkan) mempunyai pengaruh terhadap pendapatan mustahiq.

Dari hasil uji overall (uji kelayakan model) dan parsial maka persamaan regresi yang terbentuk adalah:

$\mathrm{Y}=\mathrm{a}+\mathrm{bX}$

Sedangkan untuk estimasinya:

$\ddot{Y}=49208,2+0,080 X$

Dimana:

$\ddot{Y}=$ pendapatan Mustahiq

$\mathrm{X}=$ jumlah dana (zakat) yang disalurkan

\section{Uji hipotesis}

Pada penelitian ini terdapat dua macam hipotesis yang diajukan yaitu: 1) hipotesis nihil $\left(\mathrm{H}_{0}\right)$ dan 2) hipotesis alternatif $\left(\mathrm{H}_{\mathrm{A}}\right)$. Hipotesis nihil $\left(\mathrm{H}_{0}\right)$ dalam penelitian ini adalah tidak ada pengaruh jumlah dana(zakat) yang disalurkan terhadap pendapatan mustahiq di LAZ Yayasan Solo Peduli. Sedangkan hipotesis alternatif $\left(\mathrm{H}_{\mathrm{A}}\right)$ adalah ada pengaruh jumlah dana (zakat) yang disalurkan terhadap pendapatan mustahiq di LAZ Yayasan Solo Peduli. Hipotesis ditolak jika nilai sig $<0,05$, sebaliknya hipotesis diterima jika nilai sig $>0,05$

Berdasarkan hasil analisis data dengan menggunakan teknik regresi sederhana diperoleh nilai signifikan 0,045 atau dapat dikatakan nilai sig $<0,05$, maka hipotesis nihil $\left(\mathrm{H}_{0}\right)$ ditolak, berarti hipotesis alternatif $\left(\mathrm{H}_{\mathrm{A}}\right)$ diterima, atau dapat dinyatakan bahwa jumlah dana yang disalurkan benar-benar berpengaruh secara signifikan terhadap pendapatan mustahiq.

\section{Penutup}

Hasil penelitian ini menunjukkan adanya pengaruh yang signifikan antara jumlah dana yang disalurkan terhadap pendapatan mustahiq. Ini berarti bahwa jumlah dana (zakat) yang disalurkan benar - benar mempengaruhi pendapatan mustahiq, dengan kata lain semakin tinggi dana yang disalurkan maka akan semakin tinggi pula pendapatan mustahiq.

Berdasarkan hasil analisis data dengan bantuan program Windows SPSS 
11.5 dari variabel jumlah dana (zakat) yang disalurkan dan variabel pendapatan mustahiq ditemukan besarnya pengaruh variabel jumlah dana(zakat) yang disalurkan terhadap pendapatan mustahiq sebesar 10,2 \%. yang berarti sebesar $89,8 \%$ dari pendapatan mustahiq dipengaruhi oleh faktor lain. Selain itu dari hasil uji parsial yang telah dilakukan dapat diketahui bahwa koefisien konstanta (b) dan koefisien variabel $\mathrm{X}$ (dana yang disalurkan) sama-sama mempunyai pengaruh terhadap pendapatan mustahiq.

\section{DAFTAR PUSTAKA}

Abdurrachman Qadir (2001). Zakat (Dalam Dimensi Mahdah dan Sosial), ed.1, cet.2. Jakarta: RajaGrafindo Persada.

Ahmad M. Saefuddin (1987). Ekonomi dan Masyarakat dalam Perspektif Islam. Edisi 1. Jakarta: CV Rajawali.

Bhuono Agung Nugroho (2005). Strategi Jitu Memilih Statistik Penelitian dengan SPSS. Edisi 1. Yogyakarta: Andi Offset.

Cholid Narbuko dan Abu Achmadi (2003). Metodologi Penelitian. cetakan 5. Jakarta: Bumi Aksara.

Didin Hafidhhuddin (2002). Zakat Dalam Perekonomian Modern. Jakarta: Gema Insani.

Imam Ghozali (2005). Aplikasi Analisis Multivariate dengan Program SPSS. Edisi ke 3. Semarang: UNDIP Press.

Jonathan Sarwono (2007). Analisis Jalur untuk Riset Bisnis dengan SPSS. Ed 1. Yogyakarta: Andi Offset.

Muhammad Daud Ali (1988). Sistem Ekonomi Islam Zakat dan Wakaf. cetakan 1. Jakarta: UI Press.

Muhammad Ridwan (2005). Manajemen Baitul Maal Wa Tamwil(BMT), cet 2. Yogyakarta: UII Press.

Muhammad dan Ridwan Mas'ud (2005). Zakat dan Kemiskinan Instrumen Pemberdayaan Ekonomi Umat. Yogyakarta: UII Press.

Moehar Daniel Ms. Metode Penelitian Sosial Ekonomi. cetakan ke.2. Jakarta: Bumi Aksara.

Nachrowi Djalal Nachrowi, dan Hardius Usman (2005). Penggunaan Teknik Ekonometrika. Edisi revisi. Jakarta: Rajagrafindo Persada.

Proyek Pembinaan Zakat dan Wakaf (1982). Pedoman Zakat (4). Jakarta: Departemen Agama.

Rifqi Muhammad (2006). Akuntansi Lembaga Keuangan Publik Islam, Modul Mata Kuliah. Yogyakarta: FIAI UII.

Soehadi (1999). Pengantar Metodelogi Penelitian Sosial Bisnis Manajemen. Yogyakarta: Lukman Offset. 
Mila Sartika: Pengaruh Pendayagunaan Zakat ...

Suharsimi Arikunto (1998). Prosedur Penelitian(suatu pendekatan praktek), cet. 11. Jakarta: PT Rineka Cipta.

Sukandarrumidi (2002). Metodologi Penelitian Petunjuk Praktis untuk Peneliti Pemula. cetakan 1. Yogyakarta: UGM Press.

T. Gilarso (2002). Pengantar Ilmu Ekonomi Bagian Makro, Cet ke 9. Yogyakarta: Kanisius.

\section{WAWANCARA}

Wawancara dengan Supomo (Direktur LAZ Yayasan Solo Peduli Surakarta) pada tanggal 29 April, 6 Mei, 13 Mei, dan 20 Mei 2008 di kantor LAZ Yayasan Solo Peduli dengan alamat Griya SOLOPOS lantai 3 Jl. Adisucipto No 190, Surakarta. 